\title{
Attributive clauses in Danish - and the relative irrelevance of relative clauses
}

Mortensen, Sune Sønderberg

Published in:

Nordic Journal of Linguistics

DOI:

$10.1017 / \mathrm{S} 0332586514000274$

Publication date:

2014

Document version

Publisher's PDF, also known as Version of record

Citation for published version (APA):

Mortensen, S. S. (2014). Attributive clauses in Danish - and the relative irrelevance of relative clauses. Nordic Journal of Linguistics, 37(3), 393-430. https://doi.org/10.1017/S0332586514000274 


\section{Nordic Journal of Linguistics}

http://journals.cambridge.org/NJL

Additional services for Nordic Journal of

Linguistics:

Email alerts: $\underline{\text { Click here }}$

Subscriptions: Click here

Commercial reprints: $\underline{\text { Click here }}$

Terms of use : $\underline{\text { Click here }}$

\section{Attributive clauses in Danish - and the relative irrelevance of relative clauses}

Sune Sønderberg Mortensen

Nordic Journal of Linguistics / Volume 37 / Issue 03 / December 2014, pp 393 - 430

DOI: 10.1017/S0332586514000274, Published online: 19 November 2014

Link to this article: http://journals.cambridge.org/abstract S0332586514000274

How to cite this article:

Sune Sønderberg Mortensen (2014). Attributive clauses in Danish - and the relative irrelevance of relative clauses. Nordic Journal of Linguistics, 37, pp 393-430 doi:10.1017/S0332586514000274

Request Permissions : $\underline{\text { Click here }}$ 


\section{Attributive clauses in Danish - and the relative irrelevance of relative clauses}

\section{Sune Sønderberg Mortensen}

This paper discusses criteria for distinguishing ATTRIBUTIVE (also known as adjectival) clauses and RELATIVE clauses, and argues that traditional approaches to these subclause categories and their interrelation lack consistency as well as empirical justification, from a modern Scandinavian perspective. Relative clauses are traditionally and in current Scandinavian reference grammars treated as a formally defined clause type with the attributive function as their prototypical, but not their only, constituent function. In this paper it is argued that the traditional criteria for identifying relative clauses, especially in Danish, Norwegian and Swedish, are essentially not formal but functional criteria, more or less identical to those applied to identify attributive clauses. Indeed, the modern Scandinavian languages, it is argued, hardly offer the empirical basis for a coherent category of relative clauses to be consistently distinguished on formal criteria. Rather, to account for the heterogeneous inventory of subclauses traditionally associated with relative clauses, a general outline of the functional category of attributive clauses in Danish is proposed, based on authentic spoken and written Danish discourse. Traditional definitions of attributive clauses are discussed and refined, and are shown to apply to a different and wider range of Danish subclause forms than has traditionally been recognised.

Keywords adjectival clauses, appositional clauses, attributive clauses, Danish, grammar, relative clauses, Scandinavian, subordinate clauses, syntax

Department of Nordic Studies and Linguistics, University of Copenhagen, Njalsgade 120, 5, 2300

Copenhagen S, Denmark. sunsm@hum.ku.dk

\section{INTRODUCTION}

Subordinate clauses are traditionally divided into (at least) three classes on the basis of their syntactic functions in the superordinate clause (e.g. Wiwel 1901, Mikkelsen 1911, Jespersen 1933, Hansen 1967, Quirk et al. 1985, Faarlund, Lie \& Vannebo 1997, Van Valin \& LaPolla 1997, Teleman, Hellberg \& Andersson 1999b, Cristofaro 2003, Hansen \& Heltoft 2011), for instance:

NOMINAL CLAUSES have functions that approximate to those of noun phrases $\ldots$ :

That we need a larger computer has become obvious 
ADVERBIAL CLAUSES ... function mainly as adjuncts or disjuncts ....

We left after the speeches ended

$\cdots$

RELATIVE CLAUSES generally function as ... modifiers of noun phrases

...:

a man who is lonely

(Quirk et al. 1985:1047-1048)

This general classification, in various terminological guises, is commonly considered the traditional syntactic approach to subclause classification (e.g. Hansen 1998:7; Huddleston 2002:1014). It is rarely questioned or discussed (however, see e.g. Hansen 1998; Huddleston \& Pullum 2002; Mortensen 2011a,b; Gast \& Diessel 2012), but individual versions of the traditional approach differ and definitions often carry a degree of definitory vagueness. For instance, the words 'approximate', 'mainly' and 'generally' in the definitions above open up for the possibility that the clauses in question may have functions other than the ones used in defining them. In other accounts, the clauses are classified not in terms of their canonical or potential functions, but on the basis of their ACTUAL syntactic function in a given context (e.g. Hansen \& Heltoft 2011:1499). These differences in descriptive or definitory perspectives, although quite fundamental, are often left blurred, with the result that the actual reasons why certain subclauses are standardly said to belong to one category and others to a different category tend to be unclear or unsatisfactory.

In particular, relative clauses are commonly treated as a distinct, FORMALLY defined subclause category which happens to correlate to a large extent with the FUNCTIONAL category of attributive clauses (also known as e.g. adjectival clauses and postmodifier clauses), i.e. clauses that modify the heads of e.g. noun phrases (e.g. Quirk et al. 1985, Preisler 1997, Teleman et al. 1999b, Hansen \& Heltoft 2011). But as I will illustrate in this article, the actual criteria for defining and demarcating relative clauses as a category are, from a modern Scandinavian perspective, ultimately hard to distinguish from those of attributive clauses. In general, I will argue, from a synchronic and language-specific point of view, Danish, Swedish and Norwegian hardly seem to offer the empirical basis to justify the traditional category of relative clauses.

In order to provide some clarification of the subject at hand, I will first examine the basic criterial differences, similarities and boundaries between the related categories, and explore what empirical phenomena they can actually be said to cover. The aim is, within a structural-functional framework (e.g. Engberg-Pedersen et al. 1996, Dik 1997a, Van Valin \& LaPolla 1997, EngbergPedersen et al. 2005, Hansen \& Heltoft 2011), to contribute to a more welldefined, consistent and empirically adequate framework for classifying subordinate 
clauses in Danish, focusing on the functional category of attributive clauses. Since relative clauses are traditionally considered the prototype subgroup within attributive clauses, the first part of the article deals with relative clauses. My examination of relative clauses leads me to argue that, from a modern Scandinavian perspective, relative clauses are hardly justifiable as a class of subclauses in its own right.

In the second part of the article, I illustrate that, when the basic criteria for attributive clauses are consistently applied, a wide range of Danish subclause forms are in fact able to occur as attributive clauses. Therefore the term 'attributive clause' cannot reasonably be associated merely with a few special subclause types, notably relative and appositional clauses. Instead, it must be seen as a general and functionally meaningful syntactic construction opportunity for many subclause forms.

The data explored in the article consists mainly of Danish authentic discourse, spoken or written, gathered from the spoken corpus BySoc (Project Urban Sociolinguistics), available online at http://bysoc.dyndns.org/index.cgi?EeNnGg, supplemented with data from various websites. In addition, several examples from other grammatical accounts are discussed. Moreover, since most of my empirical points are valid for the Scandinavian languages in general, and - if only indirectly - theoretically relevant for English grammar as well, the article also discusses a number of Swedish, Norwegian and English examples, gathered either from websites or from other grammatical works. Whenever examples in languages other than Danish or English are provided, the relevant language is specified.

The examples provided do not reflect quantitative research or processing. They are examples which have been gathered through systematic exploration of the sources mentioned, in order to illustrate, discuss and verify, or falsify, the descriptive and theoretical hypotheses proposed or dealt with throughout the article.

First let us take a brief look at what is commonly understood by attributive or adjectival clauses. These are part of syntactic constructions in which the subclause functions as a postmodifier within a constituent in the superordinate clause, as illustrated in (1) and (2). ${ }^{1}$

(1) så gik jeg ned og hentede en eller anden god film then went ISG down and picked.up one or other good movie [som jeg vidste han gerne ville se]. which 1SG knew 3SG certainly would watch

'Then I went down and picked up some good movie [which I knew he'd like to watch].' 
(2) der kan altså der kan opstå den uheldige situation there can you.know there can arise the unfortunate situation [at $\sim$ at vi er til fødselsdage $\sim$ og sådan that that 1PL are at birthdays and such noget] jo ik.

stuff you.know right

'Sometimes we sometimes we do get the unfortunate situation [that we are at birthday parties and stuff like that], you know, right.'

(BySoc)

In (1), the subclause functions as a postmodifier to the boldfaced noun head film 'movie'. The head is moreover premodified by the determiner phrase and adjective en eller anden god 'some good', and together these elements constitute a nominal phrase, ${ }^{2}$ functioning in turn as a direct object in the main sentence. The construction in (2) can be described in a similar way from a functional point of view, although the two examples differ in that (1) illustrates what is traditionally known as a relative clause, whereas (2) illustrates an appositional clause. The point here is that both subclauses function as attributes in a phrase, which makes them attributive clauses. Hansen \& Heltoft (2011) characterise such subclauses as follows:

[S] ubclauses can be adjectival, i.e. occurring like adjectives as modifiers in nominals. They first and foremost include so-called relative clauses ... (Hansen \& Heltoft 2011:1480, my translation)

Thus, in line with much traditional and functionally-oriented grammar (e.g. Mikkelsen 1911, Jespersen 1927, Quirk et al. 1985, Teleman et al. 1999b), Hansen $\&$ Heltoft regard adjectival clauses as clauses that function as modifiers in nominals. Teleman et al. (1999b) refer to these clauses as attributive clauses (Teleman et al. 1999b:462), a term I adopt. Thus, attributive clauses may, at this stage, be understood simply as subclauses that function as postmodifiers to (mainly) noun heads. Since their main sub-category is widely considered to be relative clauses, I will discuss these in detail in the following section.

\section{RELATIVE CLAUSES IN SCANDINAVIAN GRAMMAR}

\subsection{The correlate criterion}

In Hansen \& Heltoft's (2011) framework, relative clauses are referred to, interchangeably, as relative clauses and as 'implicative' clauses (e.g. Hansen \& Heltoft 2011:1515ff.; see also Mortensen 2011b), a notion originating from Diderichsen (1946) and employed also in e.g. Faarlund et al. (1997). Implicative (sub)clauses are defined as follows: 
The IMPLICATIVE SUBCLAUSE is defined by having a semantically empty slot, to be filled by a constituent from the superordinate clause ... (Hansen \& Heltoft 2011:1482, my translation)

This constituent, shared by subclause and superordinate clause, is expressed by what is referred to as a CORRELATE, placed in the superordinate clause, prototypically realised by a nominal (Hansen \& Heltoft 2011:1516), as in (3).

(3) Han har en hund [der kan stå på bagbenene]. $3 S G$ has a dog there can stand on hind.legs.DEF 'He has a dog [that can stand on its hind legs].'

(Hansen \& Heltoft 2011:1482)

The above subclause can thus be said to have a semantically empty subject slot which is 'filled' by the referent of the antecedent noun hund 'dog'. This way of defining relative clauses, which I refer to as the correlate criterion, is widespread, not only in Scandinavian grammar. Thus, we find similar definitions and characterisations in e.g. Givón (1990:650ff.), Faarlund et al. (1997:1054), Van Valin \& LaPolla (1997:590ff.), De Vries (2002:14), Huddleston, Pullum \& Peterson (2002:1036) and, as quoted in the following passage, Teleman et al. (1999b):

The relative subclause is introduced by an initial constituent or by the subjunction som ['which'/'that'/'who(m)'] (which can sometimes be omitted). In the former case the initial constituent is fully or partially realised by a relative pronoun or adverb which is co-referential with a constituent (the correlate) in the superordinate clause. In the latter case the subclause has an implicit constituent which is co-referential with a constituent (the correlate) in the superordinate clause. (Teleman et al. 1999b:485, my translation)

\subsection{The subordinator criterion}

In Teleman et al.'s (1999b) definition above, an additional criterion or characteristic is specified, namely the nature of the subordinator introducing the subclause. Most accounts of relative clauses involve such reference to more or less specific sets of subordinators said to introduce relative clauses, sometimes given as actual criteria, sometimes merely as prototypical characteristics of relative clauses, e.g.:

The subordinator in relative clauses can be the subjunction som ['which'/'that'/'who(m)'], an interrogative pronoun or the determiner hvilken ['which']. (Faarlund et al. 1997:1054, my translation) 
[Relative clauses] are characteristic by being introduced by som ['which'/'that'/'who(m)'], der ['there'], 'zero' or an $h v$-word [wh-word], and by the ability to occur as attribute to any nominal. (Hansen \& Heltoft 2011:308, my translation)

Relative clauses are so called because they are related by their form to an antecedent. They contain within their structure an anaphoric element whose interpretation is determined by the antecedent. This anaphoric element may be overt or covert. In the overt case the relative clause is marked by the presence of one of the relative words who, whom, whose, which, etc., as or within the initial constituent: clauses of this type we call $\boldsymbol{w h}$ relatives. In non- $\boldsymbol{w} \boldsymbol{h}$ relatives the anaphoric element is covert, a gap; this class is then subdivided into that relatives and bare relatives ... (Huddleston et al. 2002:1034)

Associating relative clauses closely with 'relative pronouns' is a well-established tradition also in Danish grammar (e.g. Wiwel 1901, Mikkelsen 1911, Jespersen 1939-40, Diderichsen 1946, Hansen 1967), even though in modern Danish, as well as in Swedish and Norwegian, relative pronouns are hardly a prototypical feature of relative clauses. As Hansen \& Heltoft (2011:1522) point out, subclauses modifying nouns or pronouns are primarily introduced by the conjunction som/ $\varnothing^{3}$ ('which'/'that'/"who(m)'/Ø), rather than by $h v$-pronouns ('wh'-pronouns), which mostly occur in archaic language or extremely formal style, as in (4).

(4) !Min kone, [hvem jeg traf i min studietid], er jurist 1SG.POSS wife whom 1SG met in 1SG.POSS study.time is lawyer 'My wife, [whom I met in my student days], is a lawyer.'

(Hansen \& Heltoft 2011:1523, my exclamation mark)

As I will discuss later, $h v$-pronouns certainly do occur in Scandinavian relative clauses, in Danish especially hvor 'where' in locative and temporal relative clauses, as well as a few $h v$-pronouns with predicational or sentential correlates, as in (5).

(5) Han bad mig blive, [hvad jeg ikke havde ventet]. $3 S G$ asked.to 1SG.ACC stay what $1 S G$ not had expected 'He asked me to stay, [which I hadn't expected].'

(Hansen \& Heltoft 2011:1528)

However, there is no synchronic evidence to suggest that Scandinavian relative clauses are PROTOTYPICALLY introduced by relative pronouns, which is probably what leads many Scandinavian grammars to incorporate both the correlate criterion and the subordinator criterion when accounting for relative clauses. 


\subsection{Other approaches}

In other accounts, relative clauses are defined or characterised without the requirement of a correlate relation or certain subordinators, e.g.:

relative clause $=$ subclause which occurs as attribute to a preceding noun or pronoun (Becker-Christensen 2010:237, my translation)

In cross-linguistic and typological frameworks, relative clauses are often defined in terms of broader notional or semantic characteristics (e.g. Dik 1997b, Comrie 1998, Givón 2001, Cristofaro 2003, Andrews 2007), e.g.:

Relative relations involve two SoAs, one of which (the dependent one) provides some kind of specification about a participant of the other (the main one). (Cristofaro 2003:195)

These other approaches to relative clauses seem to approximate the general functional understanding of ATTRIBUTIVE clauses, as initially outlined, insofar as they base the relative clause category roughly on the criterion that the subclause, in its REALISED construction, somehow modifies a superordinate argument constituent, which is more or less equivalent to saying that it functions as an attribute. These terminological overlaps between related but nonetheless different empirical phenomena contribute to a general blurring of what constitutes a relative clause. However, in the following I will concentrate on the subordinator criterion and the correlate criterion, as they are the traditional ones typically featured in, among others, Scandinavian grammars, and the ones I find truly problematic.

\section{THE PROBLEMS OF RELATIVE CLAUSES}

\subsection{Demarcating 'relative subordinators'}

As outlined above, the prototypical relative clause in Danish, Swedish and Norwegian is the som/Ø-clause, and apart from the conjunction som, a number of $h v$-pronouns ( $v$-pronouns in Swedish) are usually part of the formal criteria, explicitly or implicitly, for identifying relative clauses. Because som/Ø in the Scandinavian languages has taken over most of the work done by relative pronouns in other languages, or earlier Scandinavian stages, this conjunction is commonly considered one of the relative subordinators. However, while in Danish it can be distinguished by its general omissibility in relative constructions (see e.g. Mortensen 2011a), som alone is not a decisive signal of 'relativeness', as subclauses introduced by som may alternatively function as adverbial clauses with e.g. temporal or comparative meanings. Similarly, so-called relative pronouns are not inherently relative, as they 
can also introduce interrogative clauses (in which case they are often referred to as interrogative pronouns). Tradition and diachronic arguments aside, what determines, then, which subordinators can be considered relative subordinators? Huddleston \& Pullum characterise relative clauses as containing 'within their structure an anaphoric element whose interpretation is determined by the antecedent' (Huddleston et al. 2002:1034), although, as they acknowledge, the question whether this element is in fact anaphoric (in the case of relative clauses) or has a different referential status (in the case of interrogative clauses) is determined by other factors of the construction, as well as by pragmatics. Moreover, many linguistic forms other than those considered relative subordinators can be 'anaphoric elements whose interpretation is determined by the antecedent'. For example, Huddleston \& Pullum (2002) include when and while, which in Danish happen to translate into the conjunctions når/da and mens (see (6a); example (6b) will be referred to in the next paragraph), which are hardly recognisable as pronouns, yet are commonly considered to have the same potential for introducing 'adverbial relative clauses' (e.g. Diderichsen 1957[1946]:210ff.; Hansen \& Heltoft 2011:1530ff.), to which I will return.

(6) a. He wrote most of his poetry during the years [while he 3SG skrev det.meste af 3SG.POSS lyrik $i$ år.DEF.PL mens $3 S G$ was in Paris]. var $i$ Paris 'Han skrev det meste af sin lyrik I årene [mens han var i Paris].'

(Huddleston et al. 2002:1051, my Danish translation)

b. He wrote most of his poetry during the years [after he $3 s G$ skrev det.meste af 3SG.POSS lyrik $i$ år.DEF.PL efter $3 S G$ left Paris]. forlod Paris 'Han skrev det meste af sin lyrik i årene [efter han forlod Paris].'

Whereas in English a fairly homogenous group of 'relative subordinators' can be formed by wh-pronouns (with that as the only exception), defining a clearly demarcated and/or homogenous set of relative subordinators in Danish, as well as in Swedish and Norwegian, is not easy, given the fact that the $h v-/ v$-form cannot be an absolute criterion. Indeed, Hansen \& Heltoft include time clauses in general as a kind of relative clauses (Hansen \& Heltoft 2011:1531), which is a further widening of the category. While I do not fully agree with their analysis, as I will discuss later, it is true, also for English, for example, that time clauses, as well as many other kinds of adverbial-like clauses, can function exactly like relative clauses, e.g. in (6b) above. Since the subordinator criterion alone is thus difficult to apply in a consistent and empirically justifiable manner, at least in the Scandinavian context, grammars tend to combine it with the correlate criterion in order to account for the properties of relative clauses. I will discuss the correlate criterion in what follows. 


\subsection{What is (not) a correlate relation?}

As illustrated in example (3) above, when dealing with prototypical relative clauses such as som/Ø-clauses, the empirical data seem to match both the subordinator criterion and the correlate criterion quite well. However, relative clauses with less prototypical correlates and/or subordinators are also part of the picture, leading to a radial-like organisation of the category. For instance, less prototypical cases are presented in many grammars, including constructions with adverbial or sentential correlates, and even correlates with no manifest representation (e.g. Quirk et al. 1985, Faarlund et al. 1997, Teleman et al. 1999b, Hansen \& Heltoft 2011), as in (7), (8) and (9).

(7) Da [når ho kom heim], var alt i orden. then when $3 S G$ came home was all in order

'Then [when she came home], everything was alright.'

(Norwegian, adverbial correlate; Faarlund et al. 1997:1067)

(8) Personalomsättningen var stor, [vilket ledde till en staff.turnover.DEF was big which led to a kunskapsmässig utarmning]. knowledge.related deterioration

'The staff turnover was high, [which led to knowledge deterioration].'

(Swedish, sentential correlate; Teleman et al. 1999b:511)

(9) I took $\emptyset$ [what they offered me].

(Non-represented correlate; Quirk et al. 1985:1056)

In fact, Faarlund et al. (1997) and Hansen \& Heltoft (2011) even structure their presentations of relative clauses according to the status of the correlate in the superordinate clause, from prototypical to less prototypical cases, as the following illustrates:

Correlate represented obligatorily

- Nominal correlate (i.e. prototypical adnominal relative clauses)

- Predicate correlate (i.e. predicational or sentential relative clauses)

Correlate represented optionally

- Adverbial correlate (i.e. adverbial relative clauses)

Correlate not represented

- 'General' correlate (i.e. nominal/headless relative clauses, see Section 3.3 below)

(Hansen \& Heltoft 2011:1516, my translation)

In cases of non-represented correlates, the correlate is held to be IMPLICITLY present in the superordinate clause, meaning for instance that the subclauses in (10) and (11) 
below are both classified as (adverbial) relative/implicative clauses even though only (10) features an explicit correlate.

(10) Straks [da han trådte ind], kunne jeg se immediately when $3 S G$ stepped in could $1 S G$ see at han var syg.

that $3 S G$ was ill

'Immediately [when he entered], I could see that he was ill.'

(Hansen \& Heltoft 2011:1531)

(11) Ø [Da han trådte ind], kunne jeg se at han var syg. when $3 S G$ stepped in could $1 S G$ see that $3 S G$ was ill ' $\varnothing$ [When he entered], I could see that he was ill.'

(Hansen \& Heltoft 2011:1532)

Similarly the subclauses in (12) and (13) below are both classified as relative clauses even though only (12) features a correlate.

(12) Han gick ut och köpte allt [vad som behövdes]. $3 S G$ went out and bought all what which needed.PASS 'He went out and bought all [that was needed].'

(Swedish; Teleman et al. 1999b:506)

(13) Han gick ut och köpte $\emptyset$ [vad som behövdes]. $3 S G$ went out and bought what which needed.PASS 'He went out and bought $\emptyset$ [what was needed].'

(Swedish; Teleman et al. 1999b:506)

As noted, a basic criterion for relative clauses is the representation of a correlate in the superordinate clause, which questions the inclusion of (11) and (13) as relative clauses. Seeing them as relative clauses must be motivated by the other traditional criterion, i.e. the subordinator criterion, given that they are introduced by the 'relative subordinators' $d a$ and $v a d$, respectively. As discussed, however, many kinds of subordinators seem to ultimately qualify as relative subordinators, especially in the Scandinavian languages, which makes the status of the correlate criterion all the more important. In what follows I discuss the two less prototypical subgroups of relative clauses, i.e. nominal/headless relative clauses and adverbial relative clauses.

\subsection{The notion of nominal relative clauses}

Nominal (e.g. Quirk et al. 1985) or headless (e.g. Givón 2001) relative clauses, in the Danish tradition referred to as 'almene relativsætninger' ('general relative clauses'; Hansen \& Heltoft 2011:1538), differ, as their names indicate, from prototypical relative clauses in (at least) two respects: firstly, their correlate is obligatorily 
non-represented in the superordinate clause, and secondly, they do not function as attributes but as nominals, as illustrated in (14)-(16).

(14) You're not $\varnothing$ [who I thought you were]. (compare '... the person I thought you were')

(Quirk et al. 1985:1057)

(15) Vi gør Ø [hvad der passer os].

IPL do what there suits 1PL.ACC

'We do Ø [what we feel like].'

(Hansen \& Heltoft 2011:1538)

(16) Ø [Hvad Gud altså har sammenføjet], må et menneske what God thus has joined.together can a human.being ikke adskille.

not separate

'Ø [What God has joined together], let no man separate.'

(www.bibelselskabet.dk)

Fundamentally, the very acceptance of non-represented correlates more or less undermines the empirical basis of the relative clause category, as long as relative clauses are defined by featuring a correlate in the superordinate clause. The fact that nominal relative clauses, as they are called here, are nevertheless treated as actual relative clauses (e.g. Quirk et al. 1985:1056; Faarlund et al. 1997:1058; Teleman et al. 1999b:506; Hansen \& Heltoft 2011:1486) probably derives from their being introduced by $h v-/ v-/ w h$-pronouns, as discussed above. Still, the reason why subclauses introduced by such pronouns are called relative clauses in the first place is exactly that the pronoun relates to a superordinate antecedent and is determined by this antecedent (e.g. Huddleston et al. 2002:1034). Thus, when the antecedent is not present, the status of the pronoun is different too, as it can no longer be said to have anaphorical reference. In this respect, as discussed in e.g. Jespersen (1927:72ff.), Quirk et al. (1985:1056ff.) and Dik (1997b:80ff.), nominal relative clauses resemble INTERROGATIVE subclauses, with which they share not only the initial pronouns, but also the nominal function. In order to distinguish between them, various relative vs. interrogative characteristics are often referred to in the literature, for instance in the form of vague semantic characteristics as here:

[I]n some respects nominal relative clauses are more like noun phrases, since they can be concrete as well as abstract and can refer even to persons. (Quirk et al. 1985:1056)

Distributional differences are also occasionally mentioned, such as the fact that interrogative clauses can enter into cleft constructions, whereas nominal relative clauses cannot (e.g. Togeby 2003:97), as illustrated in (17a) and (17b). 
(17) a. De så [hvem det var der kom]. (interrogative clause)

$3 P L$ saw who it was there came

'They saw [who it was that came].' ${ }^{4}$

b. $*$ De fotograferede [hvem det var der kom]. (relative clause)

3PL photographed who it was there came

'They photographed [who it was that came].'

However, these semantic and distributional differences are hardly clear-cut reasons for the traditional separation of the subclauses into two entirely different groups. An alternative approach is to treat them, like e.g. Wiwel (1901:323), collectively as simply "pronominal clauses' ${ }^{5}$ that may pragmatically be used in different ways. In fact, the semantic difference hinted at by Quirk et al. above can be paraphrased as one of different degrees of SPECIFICITY, i.e. a more general, pragmatic and not structural, aspect of referring (see e.g. Preisler 1997:163ff.). To give a general example of the specificity domain, the indefinite nominal phrase a girl can be used for referring more or less specifically to its referents, e.g. in (18)-(20).

(18) Diamonds are a girl's best friend. (generic reference: 'girls as such')

(19) I'd love to meet a girl and settle down. (unspecific reference: 'some girl')

(20) I met a girl yesterday. (specific reference: 'a particular girl')

Correspondingly, whether a pronominal subclause is used as an interrogative clause or as a nominal relative clause is essentially a question of its referential status, that is, the degree of specificity of the pronoun, as illustrated in (21)-(23).

(21) Please tell me [what you do].

(22) I appreciate [what you do].

(23) I'm interested in [what you do]. (unspecific reference $\rightarrow$ interrogative)

(specific reference $\rightarrow$ relative)

(unspecific OR specific reference $\rightarrow$ interrogative OR relative)

Thus, in (21), the subclause content - 'what you do' - does not refer to a specified job or activity, i.e. it has unspecific reference, whereas the one in (22) refers to a specific job or activity already known by the speaker. (23) is ambiguous and may be taken either as a question or as a statement. The content and expression structure of the subclauses are the same; it is only the contextually determined specificity of reference which arguably differs. These differences of pragmatic usage indeed also explain the distributional differences observed by e.g. Togeby (2003). While the differences seem to lead many traditional grammars into dividing such subclauses into separate groups of nominal relative clauses and interrogative clauses, this division is hardly warranted, as much as we do not need to divide the indefinite article $a$ into different classes because of its different uses exemplified in (18)-(20). 
In other words, nominal relative clauses have at least as much in common with interrogative clauses as with other relative clauses, and might as well be dealt with as part of a shared category such as Wiwel's (1901) 'pronominal clauses' ${ }^{6}$ Crucially, however, if one insists on treating nominal relative clauses as a kind of relative clauses, they cannot at the same time be regarded as nominal clauses, since the assumed implicit correlate in the superordinate clause, which would warrant the relative clause label altogether, has the syntactic function of a phrase HEAD (see e.g. Faarlund et al. 1997:1048; Becker-Christensen 2010:142; Hansen \& Heltoft 2011:1515) with the subclause as its postmodifier, rendering the subclause an ATTRIBUTIVE clause, not a nominal one. Still, since these clauses are in fact nominal and not attributive, as long as no implicit constituents are forced into the analysis, their inclusion as relative clauses is hardly justified, from a Scandinavian as well as a general perspective.

\subsection{The notion of adverbial relative clauses}

The possibility of adverbial or adverbial-like relative clauses, as illustrated in (24) and (25), is accounted for in several grammars, e.g. (Diderichsen 1957[1946]:210ff.; Faarlund et al. 1997:1064ff.; Teleman et al. 1999b:507ff.; Huddleston et al. 2002:1051; Hansen \& Heltoft 2011:1530ff.).

(24) Den där veckan [när vi skulle laga andras mat]

that there week.DEF when 1PL should make other.GEN food

blev en utdragen historia.

became a longwinded story

'That week [when we were to cook other people's food] became a longwinded affair.'

(Swedish; www.pickipicki.se)

(25) Straks [da han trådte ind], kunne jeg se at immediately when $3 S G$ stepped in could $1 S G$ see that han var syg. 3SG was ill

'Immediately [when he entered], I could see that he was ill.'

(Hansen \& Heltoft 2011:1531)

However, as also mentioned in connection with example (11) above, such time clauses and certain other adverbial-like subclauses are commonly treated as relative clauses even when there is no correlate represented in the superordinate clause (e.g. Faarlund et al. 1997:1061; Teleman et al. 1999b:508; Hansen \& Heltoft 2011:1531). Analysing such subclauses as inherently relative parallels the treatment of nominal relative clauses, in that the IMPLICIT representation of a correlate in the superordinate clause is the classification basis. Still, this analysis is not empirically grounded and it arguably over-complicates the description of what might otherwise simply be treated 
as adverbial clauses, as would be the appropriate classification of, for example, the subclause in (26).

(26) Til gengæld havde vi en mindre god oplevelse, [da on.the.other.hand had 1PL a less good experience when vi spiste på Restaurant Mongaletto i Catellinaldo]. $1 P L$ dined at Restaurant Mongaletto in Catellinaldo

'On the other hand we had a less pleasant experience [when we dined at Restaurant Mongaletto in Catellinaldo].'

(www.in-italia.dk)

If an underlying motivation for such analyses is that the subordinating conjunction, in this case $d a$ 'when', is seen as a correlate constituent in the subclause (as e.g. suggested for Swedish equivalents in Teleman et al. 1999b:508), this arguably opens up for the possibility of any kind of subordinating conjunction to be treated as a correlate. Furthermore, the conjunction can hardly be said to co-refer with a constituent in the superordinate clause, as required by the relative clause definitions - rather, the entire subclause event can be said to coincide with the entire superordinate event, which only confirms that we are dealing with an adverbial relation of simultaneity. There is no obvious reason why the adverbial relation should ALSO be treated as a relative relation.

Further, in cases when adverbial-like clauses do correlate with a manifest head constituent in the superordinate clause, they arguably resemble appositional (also known as appositive) clauses more than relative clauses. These two main groups of attributive clauses are traditionally distinguished according to differences in the subclauses' internal make-up, in that an empty slot is said to characterise prototypical relative clauses (as part of the correlate criterion), whereas appositional clauses do not feature such empty slot, as illustrated in (27).

(27) Ideen [at Jorden er rund], opstod for mange år siden. idea.DEF that Earth.DEF is round emerged for many years ago

'The idea [that the Earth is round] emerged many years ago.'

(Hansen \& Heltoft 2011:1510)

Applying this criterion, it is hard to see how so-called adverbial relative clauses can be said to have an empty slot and thus qualify as relative clauses. Rather, they are complete subclauses that specify or otherwise modify a superordinate element, in constructions parallel to those of traditional appositional clauses, which may be illustrated by comparing (27) above with any 'adverbial relative clause' example, e.g. Hansen \& Heltoft's in (28). 


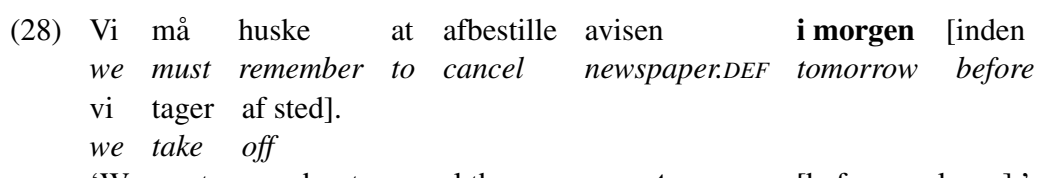

'We must remember to cancel the newspaper tomorrow [before we leave].'

(Hansen \& Heltoft 2011:1531)

In any case, an important final point must be made which echoes what was said concerning nominal relative clauses: if adverbial subclauses like the one in (26) above without an explicit correlate relation are treated as relative clauses, they cannot at the same time be regarded as adverbial clauses, since any superordinate correlate, even if implicit, has the syntactic status of a phrase head, rendering the subclause an attributive clause. Thus, when analysing a construction like (26), one must ultimately CHOOSE between treating the subclause as an adverbial clause or as a relative and thereby attributive clause, in which case the simple adverbial analysis seems the appropriate one.

In other words, the kind of semantic link connecting a relative clause to its correlate, whether implicit or manifest, is essentially the same kind of link connecting an attributive clause to its head. This link is brought about by means of syntactic construction and is not an inherent property of certain subclauses or certain subordinators. Thus, at least for the Scandinavian languages, relative clauses can hardly be regarded as a formal subclause category, but are rather a functionally defined class like that of attributive clauses. This can be illustrated by first looking at the traditional relative clause forms in Danish and the main formal and functional features traditionally said to characterise them, presented in Table 1.

Table 1 reflects the traditional understanding of relative clauses as a versatile yet coherent group of subclauses with prototypical and less prototypical members, all identified and characterised by formal features such as particular subordinators and various kinds of correlate relations realising different syntactic functions.

However, if the formal features are examined and used consistently as relative clause criteria, it is clear that the so-called relative subordinators are not 'relative' per se, as they can all introduce non-relative clauses as well, except perhaps for som/ which in Danish may be structurally distinguished by its omissibility. Further, if the correlate criterion is to make sense, only constructions featuring some kind of manifest correlate can be labelled relative constructions - otherwise anything could be said to implicitly satisfy the criterion. Consequently, since the nature of a correlate is essentially that of a phrase head, correlate constructions are necessarily attributive constructions, which leads to a revised view of relative clause features, as presented in Table 2.

In this more consistent view of relative clauses, the only clause type that fully satisfies the traditional criteria is arguably som/Ø-clauses, as discussed, and the only 


\begin{tabular}{|c|c|c|c|c|c|c|c|}
\hline & $\begin{array}{l}\text { Relative } \\
\text { subordinator }\end{array}$ & $\begin{array}{l}\text { Explicitly } \\
\text { represented } \\
\text { correlate }\end{array}$ & $\begin{array}{l}\text { Facultative } \\
\text { representation } \\
\text { of correlate }\end{array}$ & $\begin{array}{l}\text { Non- } \\
\text { represented } \\
\text { correlate }\end{array}$ & $\begin{array}{l}\text { Attributive } \\
\text { function }\end{array}$ & $\begin{array}{l}\text { Adverbial } \\
\text { function }\end{array}$ & $\begin{array}{l}\text { Nominal } \\
\text { function }\end{array}$ \\
\hline $\begin{array}{l}\text { Som/Ø- } \\
\text { relative } \\
\text { clauses }\end{array}$ & $x$ & $x$ & & & $x$ & & \\
\hline $\begin{array}{l}\text { Når-, } \\
\text { da-, } \\
\text { mens- } \\
\text { relative } \\
\text { clauses }\end{array}$ & $x$ & & $x$ & & & $x$ & \\
\hline $\begin{array}{l}H v- \\
\text { relative } \\
\text { clauses }\end{array}$ & $x$ & & & $x$ & & & $x$ \\
\hline
\end{tabular}

Table 1. Traditional view of Danish relative clauses and their main features. 


\begin{tabular}{|c|c|c|c|c|c|c|c|}
\hline & $\begin{array}{l}\text { Relative } \\
\text { subordinator }\end{array}$ & $\begin{array}{l}\text { Explicitly } \\
\text { represented } \\
\text { correlate }\end{array}$ & $\begin{array}{l}\text { Facultative } \\
\text { representation } \\
\text { of correlate }\end{array}$ & $\begin{array}{l}\text { Non- } \\
\text { represented } \\
\text { correlate }\end{array}$ & $\begin{array}{l}\text { Attributive } \\
\text { function }\end{array}$ & $\begin{array}{l}\text { Adverbial } \\
\text { function }\end{array}$ & $\begin{array}{l}\text { Nominal } \\
\text { function }\end{array}$ \\
\hline $\begin{array}{l}\text { Som/Ø- } \\
\text { relative } \\
\text { clauses }\end{array}$ & $x$ & $x$ & & & $x$ & & \\
\hline $\begin{array}{l}\text { Når-, } \\
\text { da-, } \\
\text { mens- } \\
\text { relative } \\
\text { clauses }\end{array}$ & & $x$ & & & $x$ & & \\
\hline $\begin{array}{l}\mathrm{Hv} \text { - } \\
\text { relative } \\
\text { clauses }\end{array}$ & & $x$ & & & $x$ & & \\
\hline
\end{tabular}

Table 2. Revised view of Danish relative clauses and their main features.

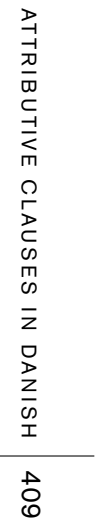


features shared by all the clause types are the basic criterion that they are part of explicit correlate constructions and, as a direct implication of this, that they function as attributes (in some cases arguably as attributes to full predicates or sentences). In other words, what essentially characterises the relative clauses is that they are attributive clauses.

\subsection{Is the category of relative clauses justified for modern Scandinavian languages?}

Provided that the only prototypical member of the relative clause category in the Scandinavian languages seems to be som/ Ø-clauses, the category as traditionally outlined is densely overpopulated by members that do not fully, if at all, meet its basic criteria. Moreover, since 'relativeness' can be boiled down to merely a way of constructing subclauses that amounts to syntactic attribution, the classificatory work offered by the relative clause category is already taken care of, as it were, by the traditional attributive clause category. The only difference is that the correlate criterion and the subordinator criterion formally excludes appositional clauses otherwise, relative clauses and attributive clauses are essentially the same category. At the same time, as illustrated, consistent and exhaustive criteria for a coherent group of relative clauses are not, and could hardly be, formulated to adequately match modern Danish, Swedish and Norwegian.

A more fruitful and consistent way to go about a formal sub-categorisation of this empirical domain might be to approach it top down, that is, to explore first the syntactic relation constituting the attributive function, and then which (groups of) subclauses, identified formally e.g. by their subordinators, can actually occur in this function and under which circumstances. One example of such subgroup is what I have referred to as pronominal clauses, which more consistently than the relative clause category cover e.g. Danish $h v$-subclauses. In the following, I propose a general description of attributive clauses in Danish, starting from an overall discussion and account of the attributive clause category.

\section{SUBCLAUSES AS ATTRIBUTES}

\subsection{Phrase constituents, not clause constituents}

As discussed initially, most accounts of attributive clauses focus on nominal phrases in which a subclause functions as postmodifier. However, specific criteria marking the boundaries of the attributive clause category against other syntactic constructions are rarely given; yet one can generally gather that clauses treated as attributive clauses are (postmodifying) PARTS OF OTHER CONSTITUENTS, forming complex phrases with them, rather than sentence constituents in their own right. If we consider this a 
criterion, there is no reason why only nominal phrases should be able to feature attributive clauses. Indeed, examples have already been given of adverbial phrases containing attributive clauses, and examples involving adjectival phrases will be discussed later. Thus, I regard subclauses that are not themselves full constituents, but postmodifiers in phrases OF ANY KIND, as attributive clauses. A special kind of attributive clauses, then, are those that do not postmodify heads of phrases but full predicates or sentences. For this reason, among others, I consider attributive clauses a more appropriate term than adjectival clauses, since 'adjectival' is traditionally associated specifically with noun modification.

To determine that a subclause is not a constituent in its own right, a topological guideline can be employed: Since a sentence constituent can normally only be fronted as a whole, attributive clauses, as opposed to nominal and adverbial clauses, cannot be fronted alone - they need their governing head, as in $(29 a-c)$.

a. Komplementærfarven er den farve [der ligger over for complementary.colour.DEF is that colour there lies opposite.to farven i farvecirklen]. colour.DEF in colour.circle.DEF

'The complementary colour is the colour [which is opposite to the colour in the colour circle].'

(www.arksite.dk)

b. $*$ [Der ligger over for farven i farvecirklen], er there lies opposite.to colour.DEF in colour.circle.DEF is komplementærfarven den farve. complementary.colour.DEF that colour '[Which is opposite to the colour in the colour circle], the complementary colour is the colour.'

c. Den farve [der ligger over for farven i that colour there lies opposite.to colour.DEF in farvecirklen], er komplementærfarven. colour.circle.DEF is complementary.colour.DEF

'The colour [which is opposite to the colour in the colour circle] is the complementary colour.'

\subsection{Non-obligatory postmodifiers}

The head of a phrase can be premodified and postmodified by words, phrases and, in the case of postmodifiers, full clauses, constituting attributive clauses. An example of a nominal phrase featuring both premodifiers and an attributive clause was given in (1) and is repeated in (30) below. 
(30) så gik jeg ned og hentede en eller anden god film then went $1 S G$ down and picked.up one or other good movie [som jeg vidste han gerne ville se]. which $1 S G$ knew $3 S G$ certainly would watch

'Then I went down and picked up some good movie [which I knew he'd like to watch].'

Postmodification of a head (or full predicate or sentence) is always structurally non-obligatory, while the postmodifying elements may be semantically/pragmatically bound to various degrees. Bound postmodifiers are in many cases referred to as complements (e.g. Quirk et al. 1985:63; Teleman, Hellberg \& Andersson 1999a:159; Pullum \& Huddleston 2002:24), although no adequate structural distinction can be made between such complements and unbound postmodifiers, and the practical application of the distinction is not clear. For example, Quirk et al. (1985) describe the postmodifying subclause in (31) below as a complement to the head more, forming a comparative clause.

(31) John is more intelligent [than Bill is].

(Quirk et al. 1985:1145)

Huddleston \& Pullum (2002) also treat such comparative clauses as complements. Certainly, textual and informational circumstances may render an expectation of the addition than Bill is, but this is merely a question of what context to assume for the example. If an alternative preceding context is specified as in (32) below, the subclause can no longer be considered bound and may be omitted.

(32) Bill is not particularly bright. John is more intelligent $\varnothing$.

This means that syntactically, the subclause can hardly be classified as anything more specific than a postmodifying, hence attributive clause. Alternatively, if any element that is felt to be semantically/pragmatically bound is to be classified as a complement, we would also expect to see e.g. restrictive relative clauses treated as complement clauses; yet both Quirk et al. and Huddleston \& Pullum treat restrictive relative clauses simply as postmodifiers (Quirk et al. 1985:1239; Huddleston et al. 2002:1034), in line with traditional grammar.

Thus, since there is hardly a clear syntactic distinction to be made between attributive clauses and complement clauses modifying phrase heads (or full predicational/sentential heads), I shall regard any syntactically non-obligatory postmodifying subclause as an attributive clause, including certain postmodifying clause types referred to as complement clauses in other frameworks.

What follows is an outline of the types of constructions that are able to feature attributive clauses in Danish, namely nominal phrases, adverbial phrases and adjectival phrases, as well as predicational and sentential structures as a peripheral kind. 


\section{TYPES OF CONSTRUCTIONS FEATURING ATTRIBUTIVE CLAUSES}

\subsection{Nominal phrases}

The most well-established group of phrases containing attributive clauses are those headed by nouns and pronouns of various kinds. They hardly require in-depth introduction as they have already been discussed and illustrated throughout the article, but a couple of examples follow.

(33) jo men de kender jo også hinanden bedre end yes but 3PL know you.know also each.other better than folk [der ellers sådan bare kommer i kirke] ik. people there otherwise like just come in church right 'Yes, but they do also know each other better than people [who otherwise just; come to the church], right?'

(BySoc)

(34) $\mathrm{Og}$ nu sidder jeg bare og venter på at ham and now sit $1 S G$ just and wait on that $3 S G . A C C$ [hvis bil jeg bakkede ind i] kontakter mig så vi kan whose car $15 G$ backed in to contacts me so 1PL can udveksle forsikringshalløj. exchange insurance.stuff 'And now I' $m$ just sitting here waiting for the guy [whose car I backed into] to contact me so we can exchange insurance stuff.'

(www.min-mave.dk)

\subsection{Adverbial phrases}

Adverbial phrases headed by adverbs or transcategorised nouns or adjectives may also contain attributive clauses. Such constructions include e.g. comparative and degree marking clauses, as in (35) and (36).

(35) jeg vil altså hellere have et badeværelse [end jeg

ISG will you.know rather have a bathroom than $1 S G$

vil have en entré].

will have an entrance.hall

'I would rather want a bathroom [than I would want an entrance hall].'

(BySoc)

(36) Han satte sig ved flygelet og spillede så smukt $3 S G$ sat 3SG.REFL by piano.DEF and played so beautifully

[at tiden stod stille].

that time stood still

'He sat by the piano and played so beautifully [that time stood still].'

(jazznyt.blogspot.com) 
In constructions like (36), the degree adverb så 'so' may be considered the head of the attributive clause. Together they form a degree adverbial phrase modifying smukt 'beautifully', which is the head of the overall manner adverbial phrase.

Time, manner and place adverbs/adverbial constructions may also function as heads of adverbial phrases featuring attributive clauses, as in (37).

(37) Senere [efter vi havde spist], sad vi og snakkede om hvad later after 1PL had eaten sat 1PL and talked about what morgendagen ville bringe. morning.day.DEF would bring

'Later [after we had eaten], we sat and talked about what tomorrow would bring.'

(www.tidslerne.dk)

\subsection{Adjectival phrases}

Moreover, adjectival phrases, often headed by adjectives in the comparative, can also be modified by certain kinds of attributive clauses, as in (38).

(38) jeg tænkte lige dengang jeg kom ind at at de den

$1 S G$ thought just that.time $1 S G$ came in that that $3 P L 3 \mathrm{SG}$

var meget større [end jeg havde forestillet mig].

was much bigger than $1 S G$ had imagined

'I was just thinking when I came in that it was much bigger [than I had imagined].'

(BySoc)

Comparative clauses like the one above are occasionally treated as a separate class of subclauses in opposition to the function-defined classes (e.g. Quirk et al. 1985:1047ff.), but the 'comparative' feature is a purely semantic one. What makes such clauses comparative is the fact that they modify adjectives, for example, and by virtue of modifying a superordinate constituent, thus realising an (adjectival) phrase, they qualify as attributive clauses.

It is worth adding that in e.g. Swedish, Norwegian and English - though not in Danish - 'emotive' adjectives are able to function as heads for attributive clauses in constructions like the ones in (39) and (40).

(39) Jag är ledsen [att jag inte har uppdaterat här på

$1 S G$ am sorry that $1 S G$ not have updated here for

hur länge som helst].

so long

'I am sorry [that I haven't been updating here for so long].'

(Swedish; blogg.dt.se/boredbeautiful) 
(40) En annen gang sa han at han var glad [at jeg an other time said $3 S G$ that $3 S G$ was glad that $1 S G$ ikke var sjefen hans] for jeg måtte være en not was boss.DEF 3SG.POSS for $1 s G$ must be an utrolig bitch å jobbe sammen med. incredible bitch to work together with

'Another time he said that he was glad [that I wasn't his boss], cause I was undoubtedly an incredible bitch to work with.'

(Norwegian; forum.kvinneguiden.no)

In some frameworks, such clauses are treated as complement/bound clauses (Quirk et al. 1985:1049; Teleman et al. 1999b:533; Huddleston 2002:964), but Preisler (1997) classifies them as postmodifiers as opposed to e.g. complements (Preisler 1997:51). As they are syntactically non-obligatory, I follow Preisler and treat them as attributive clauses. However, this kind of attributive construction is not observed in modern Danish, where a preposition is generally required after the adjective, ${ }^{7}$ meaning that such subclauses are nominal rather than attributive, as shown in (41a) and (41b).

(41) a. Men jeg var overrasket over [at jeg intet kunne but 1SG was surprised over that $1 S G$ nothing could høre da jeg sad inde i bilen med lukket dør]. hear when 1SG sat inside car.DEF with closed door 'But I was surprised [that I couldn't hear anything sitting inside the car with the door closed].'

(www.boligdebatten.dk)

b. *Men jeg var overrasket $\varnothing[$ at jeg intet kunne høre ...] but $1 \mathrm{SG}$ was surprised that $1 \mathrm{SG}$ nothing could hear 'But I was surprised [that I couldn't hear anything ... ]'

\subsection{Predicational and sentential 'heads'}

Finally, parts of sentences as well as full sentences are capable of being modified in an attributive-like relation by certain kinds of subclauses (see e.g. Theilgaard 2009, Hansen \& Heltoft 2011), as in (42)-(44).

(42) Så medmindre vi ville ændre ejerforholdet på so unless 1PL would change ownership.DEF on avisen- [hvad vi ikke havde lyst til], måtte vi newspaper.DEF which 1PL not had desire for must 1PL gå i betalingsstandsning ...

go into suspension.of.payments

'So unless we were willing to change the ownership of the newspaper, [which we didn't want], we had to file for suspension of payments.'

(Korpus DK) 

(43) de $\mathrm{s}-\sim$ eller min mor $\sim$ forlangte at jeg betalte for 3PL or 1SG.POSS mom demanded that $1 S G$ paid for at bo hjemme [hvilket jeg var lidt sur over dengang]. to live at.home which $1 \mathrm{SG}$ was a.bit angry over then 'They, or my mom demanded that I pay for living at home, [which I was a bit displeased with at the time].'

(BySoc)

(44) der måtte vi jo godt skrive med venstre hånd $£ £$ there could 1PL you.know well write with left hand [hvilket vist ikke var så almindeligt dengang den periode]. which apparently not was so common then that period 'There we were allowed to write with our left hand, [which I guess wasn't so common at that time].'

(BySoc)

I return to these predicational/sentential constructions later, and propose that they may be regarded as a peripheral type of head material.

I have given examples illustrating that nouns, pronouns, adjectives and adverbs as well as larger linguistic units can all function as heads for attributive clauses, forming nominal, adverbial and adjectival phrases, or full clauses. Still, different kinds of heads put different semantic restrictions on the clauses they govern, and vice versa, just as certain clause types are generally unable to function as attributive clauses. In the following, I examine a range of Danish subclause types, identified first and foremost by the subordinators introducing them, and account for the types of heads they are able to modify.

\section{TYPES OF ATTRIBUTIVE CLAUSES IN DANISH}

\subsection{Som/Ø-clauses}

As discussed, the central attributive clause in Danish is arguably the $s o m / \varnothing$-clause ('which'/'that'/"who(m)'/Ø-clause). The fact that the conjunction som is generally optional in Danish ${ }^{8}$ sets som/Ø-clauses apart from som-clauses, i.e. clauses of comparison or time. As opposed to som-clauses, som/Ø-clauses ONLY occur as attributive clauses, modifying nouns and pronouns of all kinds, as in (45) and (46).

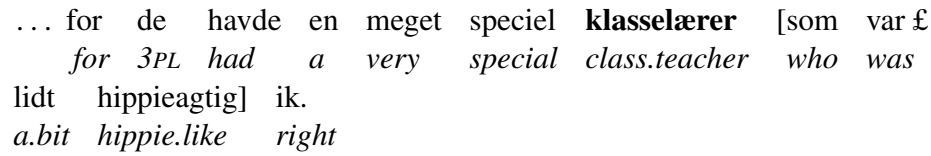

'Cause they had a very special class teacher [who was kind of a hippie], right.'

(BySoc) 
(46)

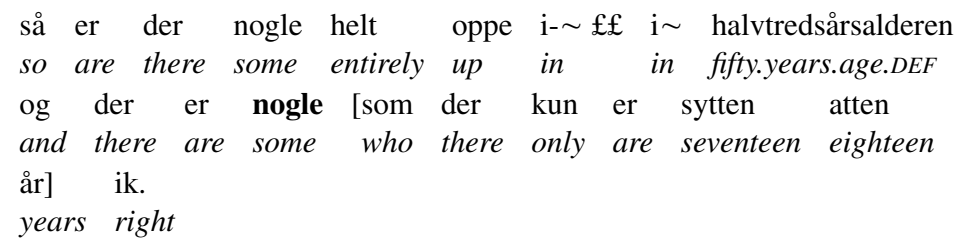

'Then there are some well into their fifties and there are some [who are only seventeen, eighteen years old], right.'

(BySoc)

\subsection{Hv-clauses}

As discussed, Danish $h v$-clauses ('wh'-clauses), which may collectively be labelled pronominal clauses, can be used for several syntactic and semantic purposes. 'Interrogative' $h v$-clauses are perhaps canonically nominal, but they do occur as attributive clauses as well in appositional-like constructions, governed by a few kinds of nouns/nominalisations expressing doubt, as in (47) and (48).

(47) Eksempelvis kan man stille sig spørgsmålet [hvem der for.example can $3 S G$ pose 3SG.REFL question.DEF who there er den egentlige indehaver af rettighederne og pligterne]. is the actual owner of rights.DEF and duties.DEF 'For example, one might ask the question [who is the true owner of the rights and the duties].'

(www.retssal.dk)

(48) Så kommer overvejelsen [hvad man egentlig kan spise: then comes consideration.DEF what $3 S G$ actually can eat om man kan spise en 'hel' tallerken]. whether $3 S G$ can eat a full dish 'Then there is the consideration [what you can actually eat: whether you can eat a 'full' dish].'

(khorkhoi.wordpress.com)

Further, in special contexts where highly formal or archaic language is used, a few $h v$-clauses, notably hvem- and hvad-clauses ('who(m)'-clauses and 'what'/"which'clauses), and clauses introduced by the possessive pronoun $h v i s$ 'whose', can function much like som/Ø-clauses, modifying nouns and pronouns, as in (49).

(49) Jeg vil være barmhjertig imod den, [hvem jeg er $1 S G$ will be merciful towards $3 S G$ whom $1 S G$ am barmhjertig imod], og forbarme mig over den, merciful towards and mercy 1SG.ACC.REFL over $3 S G$ [hvem jeg forbarmer mig over]. whom 1SG mercy 3SG.ACC.REFL over

'I will have mercy on he [whom I have mercy on], and compassion for HE [whom I have compassion for].' 
Moreover, $h v$-subordinators combined with prepositions can modify nouns and pronouns, also mainly in formal or archaic-style contexts, as illustrated in (50).

(50) De er trænet $i$ at bringe andre mennesker $i$ en $3 P L$ are trained in to bring other human.beings in a form for trance, [hvorunder de kan påvirke dette form of trance where.under $3 P L$ can influence this menneskes adfærd]. human.being's behaviour 'They are trained to bring other people into a form of trance, [in which they can influence this person's behaviour].'

(www.kentaurnet.dk)

These are all constructions in which $h v$-clauses modify nouns or pronouns. As discussed, some $h v$-clauses can realise 'sentential attributive clauses', modifying the entire superordinate clause or a predicate contained in it. In Section 5.4 above, I gave examples of hvilket-clauses ('which'-clauses); other significant types include e.g. hvorfor-clauses ('why'-clauses) and hvorimod-clauses ('whereas'-clauses), as in (51a) and (52a).

(51) a. Havnen var således fyldt op, [hvorfor vi valgte at sejle harbour.DEF was thus filled up why 1PL chose to sail over til Getterön].

over to Getterön

'Thus the harbour was packed, [which was why we chose to sail over to Getterön].'（www.danmarkstursejlerforening.dk)

b. *[Hvorfor vi valgte at sejle over til Getterön], var havnen why 1PL chose to sail over to Getterön was harbour således fyldt op.

thus filled up

'[Which was why we chose to sail over to Getterön], thus the harbour was packed.'

(52) a. Det ene studie påviste ingen effekt, [hvorimod det andet viste the one study showed no effect whereas the other showed positiv effekt af rehabilitering]. positive effect of rehabilitation

'The first study did not show any effect, [whereas the other one showed a positive effect of rehabilitation].'

(www.ucviden.dk)

b. *[Hvorimod det andet viste positiv effekt af rehabilitering], whereas the other showed positive effect of rehabilitation påviste det ene studie ingen effect. showed the one study no effect '[Whereas the other one showed a positive effect of rehabilitation], the first study did not show any effect.' 
Some accounts treat such subclauses as adverbial or adverbial-like clauses (e.g. Quirk et al. 1985, Togeby 2003, Hansen \& Heltoft 2011; but see discussion in Theilgaard 2009:55-56). However, this classification is unsatisfactory as the clauses lack the ability to be fronted, as shown in (51b) and (52b) above, an ability which characterises other adverbial clauses in Danish (e.g. Hansen \& Heltoft 2011:1541).

Since these clauses do not modify single heads but entire clauses, it is impossible to determine whether they could be fronted along with their 'head', as in the case of other attributive clauses. Still, the fact that they cannot be fronted separately ${ }^{9}$ might be seen as evidence in favour of treating them as attributive clauses, since attributive clauses are always POSTmodifiers as opposed to e.g. adverbial clauses. While Theilgaard argues that they do not have a constituent function at all (Theilgaard 2009:61), I find it reasonable to treat them as peripheral members of the attributive clause category.

The distribution of the attributive $h v$-clauses differ, such that some can only express interrogative meaning, modifying a few specific noun heads, e.g. hvordanclauses ('how'-clauses). Others can modify most kinds of nouns and pronouns as well as (parts of) full sentences, e.g. hvad-clauses ('what'/"which'-clauses), while some $h v$-clauses can only modify predicates and full sentences, e.g. $h$ vorimod-clauses ('whereas'-clauses). A final $h v$-clause is especially versatile, namely the $h v o r$-clause (roughly: 'where'/'when'-clause), which is able to occur not only in all of the functions mentioned above, but also as attribute to adverb heads, as in (53) and (54).

(53) han ha-han skrev jo han førte dagbog $£$ som skulle

$3 S G \quad 3 S G \quad$ wrote you.know $3 S G$ kept diary.INDF that should

udgives nu [hvor han blev pensioneret].

publish.PASS now where $3 S G$ became retired

'He did write he kept a diary that was meant to be published now [that he retired].'

(BySoc)

(54) Det ville være en måde at hindre at politikerne kørte helt ud it would be a way to prevent that politicians.DEF went entirely out [hvor al mening forsvinder]. where all sense disappears

'It would be a way to prevent the politicians from going all the way out [where all sense disappears].'

(www.180grader.dk)

\subsection{At/Ø- and om-clauses}

The primary attributive function of at/Ø-clauses ('that'/Ø-clauses) and $\mathrm{om}$-clauses ('if'/'whether'-clauses) is that of apposition, as in (55) and (56), quite similar to interrogative attributive $h v$-clauses. 
(55) Den anklage, [at der er for få franskmænd blandt for mange that accusation that there are too few Frenchmen among too many udlændinge], er også blevet rettet mod operaen i Paris. foreigners is also been direct.PASS against opera.DEF in Paris 'The accusation [that there are too few Frenchmen among too many foreigners] has also been directed at the opera in Paris.'

(dvm.nu)

(56) Debatten [om der er andre veje til Gud end gennem Kristus] debate.DEF whether there are other paths to God than through Christ blussede op igen.

lit up again

'The debate [whether there are other paths to God than through Christ] arose again.'

(www.kirkeligtcentrum.dk)

While om-clauses roughly share their distributional pattern with interrogative $h v$-clauses, at/Ø-clauses can modify a broader range of nouns referring to opinions, beliefs, statements etc. Similarly to som/Ø-clauses, at/Ø indicates that at is optional in various contexts, including attributive clauses, as illustrated in (57).

(57) Engang under et syretrip, fik mig og en kammerat den idé [Ø vi once during an acid.trip got 1 SG.ACC and a friend that idea 1PL skulle hoppe i svømmingpoolen] selvom det var tidligt forår. should jump in swimmingpool.DEF although it was early spring 'Once during an acid trip, me and my friend got the idea $[\varnothing$ we should jump into the swimmingpool] although it was early spring.'

(psychedelia.dk)

Finally, as discussed in Section 5.2 above, at/Ø-clauses can modify adverb heads in the characteristic degree marking construction. Note that also så-clauses ('so (that)'-clauses) can occur in this kind of construction, e.g. in (58).

(58) de blev sgu så forskrækkede [så de sprang i havnen $3 P L$ became by.God so scared so 3PL jumped in harbour.DEF dernede].

down.there

'They got so scared [they jumped into the harbour down there].'

(BySoc)

\subsection{End-clauses}

End-clauses ('than'-clauses) represent one of the few clause types apart from som/Øclauses that can only function as attributes (see e.g. Becker-Christensen 2010:144). They do so as modifiers of e.g. comparative adverbs, adjectives and other elements involved in comparisons or distinguishing relations, and thus may be part of adjectival, adverbial or nominal phrases, the former and the latter exemplified in (59) and (60). 
(59) politisk og $£$ og $\mathrm{f}$ - med hensyn til parforhold og alt muligt andet politically and and with regard to relationships and all possible else der er der er de sgu mere konservative [end jeg kan huske] there are there are 3PL by.God more conservative than $1 S G$ can remember i hvert fald ik. in any case right

'Politically and concerning relationships and lots of other things they are certainly more conservative [than I remember] anyway right.'

(BySoc)

(60) altså jeg har al- aldrig kendt andet [end at min bedste har you.know I have never known other than that my granny has boet hos os].

lived with us

'You know I have never known anything other [than that my granny has lived with us].'

(BySoc)

\subsection{Time, place and manner clauses, etc.}

A range of subclauses that are typically recognised as adverbial clauses can also occur in the attributive function. For instance, attributive time clauses were discussed earlier - and while I oppose to the tradition of treating time clauses as inherently 'relative', it is indeed relevant to point out their ability to function in this way, i.e. as attributive clauses. Time clauses are not the only 'adverbial-like' subclauses that can occur as attributes. In fact, any subclause that can function as an adjunct clause, as opposed to a disjunct clause (e.g. Quirk et al. 1985:1070ff.), can also have attributive function (see Mortensen 2011a for a detailed distributional analysis of such subclauses). For instance, a typical time clause such as a mens-clause ('while'-clause) can occur as adjunct and as attribute, as illustrated in (61) and (62).

(61) $\operatorname{og} \sim £$ en anden skal så holde øje med kassen [mens jeg $£$ lige and an other must then keep eye with till.DEF while 1SG just

går ned i kælderen].

go down in basement.DEF

'And someone else must then keep an eye on the till [while I pop down to the basement].'

(Adjunct clause; BySoc)

(62) I perioden [mens Michael Jackson boede på ranchen] var in period.DEF while Michael Jackson lived on ranch.DEF was han meget gæstfri...

$3 S G$ very hospitable

'During the period [while Michael Jackson lived on the ranch], he was very hospitable.' 
Subclauses like these designate concrete, objective circumstances of what is expressed in the superordinate clause, such as time, place, manner, cause, condition etc. DISJUNCT clause forms, on the other hand, as in (63a), expressing speakersubjective circumstances such as reason, concession, justification, contrast etc., cannot be constructed with attributive function, as illustrated in (63b).

a. Men altså når først man stræber på karaktererne så f får
but you.know when first $3 S G$ aspires on marks.DEF then get
man ingen venner oppe på skolen $£$ [selvom det lyder som
3SG no friends up on school.DEF although it sounds like
sådan noget snob som folk de går og siger].
such some snobbery that people 3PL go and say

'But you know, once you strive for high marks, then you don't get any friends up at the school, [although it sounds like some kind of snobbery that people are just saying].'

b. IDette rygte [Disjunct clause; BySoc) this rumour although it sounds like such some snobbery som folk de går og siger], er sandt. that people $3 P L$ go and say is true

'This rumour, [although it sounds like some kind of snobbery that people are just saying], is true.'

c. [Selvom det lyder som sådan noget snob som folk de although it sounds like such some snobbery that people they går og siger], er dette rygte sandt. go and say is this rumour true

'[Although it sounds like some kind of snobbery that people are just saying], this rumour is true.'

Even when the selvom-clause ('although'-clause) is forced into a position adjacent to a potential head constituent as in (63b), the syntactic relation between them is not one of attribution. Instead, the selvom-clause must be interpreted as a parenthetical addition modifying the entire superordinate clause in an adverbial relation, which is illustrated by the fact that the subclause can easily be fronted separately, as in (63c) above.

A number of subordinators can introduce both adjunct and disjunct clauses, including a range of conjunctions featuring a temporal as well as a non-temporal variant. Such variants have different semantic and syntactic properties reflecting how closely they are integrated in the superordinate nucleus (see e.g. Quirk et al. 1985; Haegeman 2006; Mortensen 2006, 2011a; Verstraete 2007; Hansen \& Heltoft 2011), including the distributional difference that only potential adjunct clauses are able to function as attributes.

Moreover, due to specific lexical differences, certain adjunct-like clause types are more easily constructed as attributive clauses than others. For instance, most time clauses readily modify nouns and time adverbials of all kinds, as discussed and 
illustrated in Section 3.4 above, whereas e.g. causal fordi-clauses ('because'-clauses) require more specific types of heads, as illustrated in (64) to (67).

(64) Tiden [indtil, der er en unge i reden], er den allermest kritiske med time.DEF until there is a chick in nest.DEF is the farmost critical with hensyn til forstyrrelser.

regard to disturbances

'The time [until there is a chick in the nest] is the far most critical with regard to disturbances.'

(www.naturstyrelsen.dk)

(65) Jeg har også et ansigt, der er så hævet, at jeg ligner 1SG have also a face there is so swollen that 1SG look.like

Brian Nielsen [lige efter at han havde bokset 12 omgange], Brian Nielsen right after that $3 S G$ had boxed 12 rounds bare at Brian var pænere. only that Brian was prettier

'I do have a face so swollen that I look like Brian Nielsen [right after he had done 12 rounds of boxing], except that Brian was prettier.'

(livetsomsdan.blogspot.com)

(66) I perioden [siden hun skrev professionel på visitkortet], in period.DEF since $3 S G$ wrote professional on business.card.DEF har Julie Tvede spillet otte turneringer på Futures Tour... has Julie Tvede played eight tournaments on Futures Tour 'During the period [since she wrote professional on her business card], Julie Tvede has played eight tournaments on the Futures Tour.'

(www.golfonline.dk)

(67) Kender i følelsen af ubetinget glæde? Glæde [fordi det næsten know 2PL feeling.DEF of unconditioned joy joy because 3SG almost er sommer], glæde [fordi fuglene synger], glæden [fordi is summer joy because birds.DEF sing joy.DEF because man er til]. 3SG exists

'Do you know the feeling of unconditioned joy? Joy [because it's almost summer], joy [because the birds are singing], the joy [because you exist].'

(dindebat.dk)

Thus, while the time clauses above all modify heads designating more or less concrete entities or specifications, the complexity of a causal relation like the one in (67) requires that a predication or a similarly complex entity be incorporated within the head constituent. For this reason, attributive causal clauses and other semantically complex clause types seem to be restricted to nominal phrases headed by certain kinds of nouns, seeing that e.g. adverb and adjective heads can hardly express predicational content. Glade 'joy', in the above case, can for instance be said to incorporate a 
predication such as at vare glad 'being joyful', to which the modifying subclauses express different causes. Note that analysing the fordi-clauses as ADVERBIAL clauses would be inappropriate: even if glaede is seen as part of the preceding clause, the causal relations cannot be interclausal - only glade $(n)$ is modified.

Similar kinds of complex predicational content can also be expressed through for instance nominalisations, as in (68).

(68)

$\begin{array}{llllll}\text { Ganske vist } & \text { indeholder } & \text { lovforslaget } & \text { et forbud } & \text { mod } \\ \text { quite } & \text { certainly } & \text { contains } & \text { legislation.proposal.DEF } & \text { a prohibition } & \text { against }\end{array}$

fyring [fordi man siger nej til at gå på deltid].

dismissal because $3 S G$ says no to to go on part.time

'Certainly, the proposed legislation contains prohibition of dismissal [because you say no to going part-time].'

(www.hk.dk)

Similar preferences apply to other semantically complex adjunct-like clauses such as e.g. hvis-clauses ('if'-clauses) and så-clauses ('so (that)'-clauses), as in (69) and (70).

(69) Har din virksomhed overblik over sine mest has 2SG.POSS company overview over 3SG.POSS most

kritiske kontraktsrisici og konsekvensen, [hvis de aktualiseres]? critical contract.risks and consequence.DEF if they actualise.PASS 'Is your company aware of its most critical contract risks and the consequence [if they are actualised]?'

(www.marsh.dk)

(70) Det er en ensomhed, som er forbundet med et talent, [så man it is a loneliness which is tied to a talent so $35 G$ tror, det er løgn].

thinks it is lie

'It is a loneliness which is tied to a talent [so you won't believe it].'

(www.kirkeogfilm.dk)

Finally, the general fact that potential adjunct clauses can modify predicational content both in terms of adverbial modification and in terms of attributive modification calls for a clarification of the boundary between the two kinds of syntactic relations. For instance, it is not necessarily clear-cut whether the mens-clause ('while'-clause) in (71) is an adverbial clause or an attributive clause.

(71) Ved et simpelt tyveri af en smartphone [mens man bærer den at a simple theft of a smartphone while $3 S G$ carries it på sig], er man dækket af sin indboforsikring. on 3SG.REFL is $3 S G$ covered by 3SG.POSS house.insurance 'In the case of a simple theft of a smartphone [while you are carrying it on you], you are covered by your house insurance.' 
Yet, considering that et simpelt tyveri af en smartphone 'a simple theft of a smartphone' has the structure of a nominal phrase (i.e. the prepositional object of ved 'in the case of'), the subclause is most appropriately classified as an attributive clause modifying the head tyveri 'theft'. Still, this construction seems closer to an adverbial construction than most of the previous attributive constructions discussed, due to the fact that the head is part of a full predication, i.e. a semantic unit normally modified by e.g. time adverbials. The attributive relation adds to a densely packaged information unit suited for specifying a certain 'type of damage'. Other kinds of cases that might be considered borderline examples, include superordinate infinitives modified by adjunctive clauses, as in (72).

(72) Det er vigtigt, at få sine børn [mens man er ung]. it is important to have 3SG.POSS children while $3 S G$ is young 'It's important to have your children [while you are young].'

(www.preecom.dk)

The mens-clause resembles an attributive clause in terms of functioning as a modifier within a phrase, i.e. an infinitive phrase. However, the criterion that an attributive clause must be non-obligatory is hardly met in this case, as leaving out the mensclause would render the sentence somewhat incomplete, as illustrated in (73).

(73) !Det er vigtigt at få sine børn.

it is important to have 3sG.POSS children

'It's important to have your children.'

Rather, the mens-clause might be treated as a predicate satellite (see e.g. Dik 1997a:51), i.e. a kind of bound adverbial clause constituting an integral part of the verbal activity itself. Such borderline examples are part of any classification approach and illustrate the inevitable fuzziness of grammatical categories. The success of a classification approach, then, should depend on whether it offers fewer problematic borderline cases and greater explanatory power than its alternatives.

The distributional patterns observed for the various subclause forms analysed throughout the article can be summarised in Table 3, in which the $\mathbf{X}$ s illustrate which of the subclause types can occur as attributes in the three different phrase types and as part of predicational/sentential constructions.

Table 3 confirms that som/ $\varnothing$ is arguably the most general attributive subordinator in Danish, and that a nominal head is the prototypical base for attributive clauses. The fourth column is shaded to illustrate that predicational/sentential attributive constructions represent a peripheral case. Finally, the bottom row is void of $\mathbf{X s}$ to illustrate that certain subclause forms/variants cannot occur as attributive clauses at all. This organisation of the distributional patterns highlights two prototypicity hierarchies, showing on the one hand e.g. that adjectival phrases (let 


\begin{tabular}{|c|c|c|c|c|}
\hline & $\begin{array}{l}\text { Nominal } \\
\text { phrases }\end{array}$ & $\begin{array}{l}\text { Adverbial } \\
\text { phrases }\end{array}$ & $\begin{array}{l}\text { Adjectival } \\
\text { phrases }\end{array}$ & $\begin{array}{l}\text { Predicational/ } \\
\text { sentential } \\
\text { constructions }\end{array}$ \\
\hline Som/Ø-clauses & $x$ & $x$ & $x$ & $x$ \\
\hline At/Ø-clauses & $x$ & $x$ & $x$ & \\
\hline End-clauses & $x$ & $x$ & $x$ & \\
\hline$S \stackrel{\text {-clauses }}{ }$ & $x$ & $x$ & $x$ & \\
\hline $\begin{array}{l}\text { Time and manner } \\
\text { (adjunct-like) clauses }\end{array}$ & $x$ & $x$ & & \\
\hline Hvor-clauses & $x$ & $x$ & & \\
\hline $\begin{array}{l}H v \text {-clauses (except } \\
\quad h v o r-)\end{array}$ & $x$ & & & $x$ \\
\hline Om-clauses & $x$ & & & \\
\hline Fordi-clauses & $x$ & & & \\
\hline Hvis-clauses & $x$ & & & \\
\hline
\end{tabular}

Reason, adversative, concessive etc. (disjunct-like) clauses

Table 3. Possible attributive clause constructions in Danish. (The fourth column is shaded to illustrate that predicational/sentential attributive constructions represent a peripheral case.)

alone predicational/sentential constructions) are the ones least capable of featuring attributive clauses, and on the other hand that e.g. hvis-clauses and fordi-clauses are the least versatile forms to occur as attributive clauses.

\section{CONCLUDING REMARKS}

I have illustrated that traditional accounts of relative clauses, at least in a Scandinavian grammar context, significantly lack definitory clarity and consistency, as well as empirical justification. On this basis I have argued that Scandinavian subclause classification has no obvious benefit from its traditional and still widespread relative clause categories defined in terms of correlate relations and more or less explicit sets of relative subordinators, since this understanding of relative clauses can essentially be reduced to the functional class of attributive clauses, i.e. a syntactic construction rather than an inherent feature of certain subclauses.

Regardless of the status one assigns to relative clauses, the class of attributive clauses is itself traditionally not clearly defined and demarcated. For this reason, I have discussed existing accounts of attributive clauses and similar categories, and on this basis proposed an expanded, more clearly specified and more consistent concept of attributive clauses than is provided in the Scandinavian reference grammars discussed. The discussion and clarification of these criteria is relevant not only in a Danish 
and Scandinavian context, but may contribute to more consistent classification of subclauses in other languages, e.g. English. More specifically, the proposed account of attributive clause constructions offers a framework for dealing with a range of previously problematic subclause constructions, such as adjunct-like subclauses functioning as attributes.

A general observation emerging from this examination of Danish attributive clause constructions is that most subclause forms are in fact able to be constructed as attributive clauses. One overarching functional purpose of attributive constructions can hardly be identified, but in many cases attribution is a means of packaging clause content into dense analytical information units. In addition, constructions with a governing head often allow speakers to specify in greater detail the intended meaning of a subclause, e.g. the fact that ... vs. the contention that ...; and the moment when ... vs. the period when ..., etc.

As also discussed in Mortensen (2011a, b, 2013), many traditional grammars conflate or confuse the analytical levels of form and function in the description of subclauses, which has the unfortunate consequence that subclauses are often classified according to several, sometimes contradictory, sometimes doublet, criteria at once, blurring the actual benefit of the classification itself. The present attempt at clarifying a part of the functional level of subclause classification on the one hand, and examining what linguistic forms are involved in it on the other, can hopefully contribute not only to more consistent but also more empirically illuminating treatments of subclauses.

\section{ACKNOWLEDGEMENTS}

I would like to thank Torben Juel Jensen, Peter Harder, Marie Herget Christensen and Janus Mortensen as well as Nordic Journal of Linguistics editors Matti Miestamo and Ewa Jaworska, and anonymous reviewers for insightful comments on previous versions of this paper.

\section{NOTES}

1. For each example the source is provided in parentheses, except for examples which are constructed/derived from other examples. Further, for each example, the relevant subclause under analysis is framed by square brackets, and the relevant head constituent is boldfaced. English translations follow the Danish examples, but are not accounted for analytically. In BySoc excerpts, $\sim$ marks a hesitation. $£$ and $£ £$ mark 'pause' and 'long pause'. A hyphen marks an unfinished word. Examples considered grammatically impossible are preceded by an asterisk, and examples considered highly odd are preceded by an exclamation mark.

2. The concept 'nominal phrase' - as well as 'adjectival phrase' and 'adverbial phrase' - used in this paper is based on the traditional understanding of phrase structure, as formulated for Danish in e.g. Diderichsen (1946), roughly corresponding to that of e.g. Quirk et al. (1985) and Teleman, Hellberg \& Andersson (1999c). 
3. This is also the case in Swedish and Norwegian. In relative som-clauses, som is sometimes omitted, and I therefore refer to these clauses as som/Ø-clauses.

4. These examples from Togeby (2003) are not easily translated into English, but they correspond to cleft constructions like e.g. Does anyone know [who it was that was murdered in viper years ago]?, (from www.topix.com).

5. Not all pronominal clause types can be used as both interrogative and 'relative' clauses (see Section 6.2).

6. See Mortensen (2011a) for another collective treatment of such subclauses as members of a formally defined class called NUCLEAR CLAUSES, contained in a comprehensive five-part classification framework.

7. In Swedish and Norwegian, such constructions may or may not include a preposition, whereas in English, prepositions are generally not included.

8. Contrary to what appears to be a common assumption (e.g. Becker-Christensen 2010:143; Hansen \& Heltoft 2011:1521; Pedersen 2011:231), even in parenthetical attributive clauses the conjunction som can be left out, as illustrated in Mortensen (2011a), mostly - but not exclusively - in constructions involving the dummy subject der 'there'. (In a series of coordinated som/Ø-clauses, however, som appears to be obligatory in all but the first clause.)

9. Theilgaard (2009) discusses examples of such clauses in 'initial' position, but recognises that they are not able to occur in the 'fundament' position (or 'be fronted' in the terminology used here), i.e. the position immediately preceding the finite verb (Theilgaard 2009:51).

\section{REFERENCES}

Andrews, Avery D. 2007. Relative clauses. In Timothy Shopen (ed.), Language Typology and Syntactic Description, vol. II: Complex Constructions, 2nd edn., 206-236. Cambridge: Cambridge University Press.

Becker-Christensen, Christian. 2010. Dansk syntaks. Frederiksberg: Samfundslitteratur.

Comrie, Bernard. 1998. Rethinking the typology of relative clauses. Language Design 1, 59-86.

Cristofaro, Sonia. 2003. Subordination. Oxford: Oxford University Press.

De Vries, Mark. 2002. The Syntax of Relativization. Utrecht: Landelijke Onderzoekschool Taalwetenschap.

Diderichsen, Paul. 1946. Elementar dansk grammatik. København: Nordisk Forlag.

Diderichsen, Paul. 1957[1946]. Elementar dansk grammatik, 2nd edn. København: Gyldendal.

Dik, Simon C. 1997a. The Theory of Functional Grammar. Part 1: The Structure of the Clause, second, revised edition, edited by Kees Hengeveld. Berlin: Mouton de Gruyter.

Dik, Simon C. 1997b. The Theory of Functional Grammar. Part 2: Derived and Complex Structures, second, revised edition, edited by Kees Hengeveld. Berlin: Mouton de Gruyter.

Engberg-Pedersen, Elisabeth, Michael David Fortescue, Peter Harder, Lars Heltoft \& Lisbeth Falster Jakobsen (eds.). 1996. Content, Expression and Structure: Studies in Danish Functional Grammar. Amsterdam: John Benjamins.

Engberg-Pedersen, Elisabeth, Michael David Fortescue, Peter Harder, Lars Heltoft \& Lisbeth Falster Jakobsen (eds.). 2005. Dansk funktionel lingvistik: En helhedsforståelse af forholdet mellem sprogstruktur, sprogbrug og kognition. København \& Roskilde: Københavns Universitet/Handelshøjskolen i København \& Roskilde Universitetscenter. 
Faarlund, Jan Terje, Svein Lie \& Kjell Ivar Vannebo. 1997. Norsk referansegrammatikk. Oslo: Universitetsforlaget.

Gast, Volker \& Holger Diessel (eds.). 2012. Clause Linkage in Cross-linguistic Perspective: Data-driven Approaches to Cross-clausal Syntax. Berlin: Mouton De Gruyter.

Givón, Talmy. 1990. Syntax: A Functional-typological Introduction, vol. 2. Amsterdam: John Benjamin.

Givón, Talmy. 2001. Syntax: An Introduction, rev. edn., 2 vols. Amsterdam: John Benjamins.

Haegeman, Liliane. 2006. Argument fronting in English, Romance CLLD, and the left periphery. In Raffaella Zanuttini, Héctor Campos, Elena Herburger \& Paul Portner (eds.), Cross-linguistic Research in Syntax and Semantics: Negation, Tense and Clausal Architecture, 27-52. Washington, D.C.: Georgetown University Press.

Hansen, Aage. 1967. Moderne dansk 3. København: Det Danske Sprog- og Litteraturselskab/Grafisk Forlag.

Hansen, Erik. 1998. Kriterier for inddeling af ledsætninger. In Peter Colliander \& Iørn Korzen (eds.), Ny forskning i grammatik 5: Sophienbergsymposiet, 7-22. Odense: Odense Universitetsforlag.

Hansen, Erik \& Lars Heltoft. 2011. Grammatik over det danske sprog. København \& Odense: Det Danske Sprog- og Litteraturselskab/Syddansk Universitetsforlag.

Huddleston, Rodney. 2002. Content clauses and reported speech. In Huddleston \& Pullum et al., 947-1030.

Huddleston, Rodney \& Geoffrey K. Pullum et al. 2002. The Cambridge Grammar of the English Language. Cambridge: Cambridge University Press.

Huddleston, Rodney, Geoffrey K. Pullum \& Peter Peterson. 2002. Relative constructions and unbounded dependencies. In Huddleston \& Pullum et al., 1031-1096.

Jespersen, Otto. 1927. A Modern English Grammar on Historical Principles, Part III. Heidelberg: Carl Winters Universitätsbuchhandlung.

Jespersen, Otto. 1933. Essentials of English Grammar. London: Allen \& Unwin.

Jespersen, Otto. 1939-40. Ledsætningernes (bisætningernes) systematik. Acta Philologica Scandinavica 14, 65-74.

Mikkelsen, Kr. 1911. Dansk ordföjningslare: Med sproghistoriske tillag. Håndbog for viderekomne og laerere. København: Hans Reitzels Forlag.

Mortensen, Sune Sønderberg. 2006. Temporale konjunktioner i dansk. MA thesis, Roskilde University.

Mortensen, Sune Sønderberg. 2011a. A distributional approach to functional Danish subclause classification. Acta Linguistica Hafniensia 43(2), 127-175.

Mortensen, Sune Sønderberg. 2011b. Problemer og udveje i dansk ledsætningsklassifikation. In Per Durst-Andersen \& Henrik Høeg Müller (eds.), Ny forskning i grammatik 18, 225-247. Odense: Syddansk Universitetsforlag.

Mortensen, Sune Sønderberg. 2013. Klassifikation af ledsatninger i dansk. Ph.D. thesis, University of Copenhagen.

Pedersen, Karen Margrethe. 2011. Relativt som i grammatisk, historisk og geografisk belysning. 13. Mфde om Udforskningen af Dansk Sprog, 225-235. Aarhus: Institut for Æstetik og Kommunikation, Aarhus University.

Preisler, Bent. 1997. A Handbook of English Grammar on Functional Principles, 2nd edn. Aarhus: Aarhus University Press.

Pullum, Geoffrey K. \& Rodney Huddleston. 2002. Preliminaries. In Huddleston \& Pullum et al., 1-41. 
Quirk, Randolph, Sidney Greenbaum, Geoffrey Leech \& Jan Svartvik. 1985. A Comprehensive Grammar of the English Language. London: Longman.

Teleman, Ulf, Staffan Hellberg \& Erik Andersson. 1999a. Svenska Akademiens grammatik 1: Indledning: Register. Stockholm: Svenska Akademien.

Teleman, Ulf, Staffan Hellberg \& Erik Andersson. 1999b. Svenska Akademiens grammatik 4: Satser och meningar. Stockholm: Svenska Akademien.

Teleman, Ulf, Staffan Hellberg \& Erik Andersson. 1999c. Svenska Akademiens grammatik 4: Fraser. Stockholm: Svenska Akademien.

Theilgaard, Liisa. 2009. Prædikatsrelativsætninger i dansk: En empirisk unders $\emptyset$ gelse af hvad- og hvilket-relativsætninger. MA thesis, University of Copenhagen.

Togeby, Ole. 2003. Fungerer denne satning? Funktionel dansk sproglare. København: Gads Forlag.

Van Valin, Robert D., Jr. \& Randy J. LaPolla. 1997. Syntax: Structure, Meaning and Function. Cambridge: Cambridge University Press.

Verstraete, Jean-Christophe. 2007. Rethinking the Coordinate-Subordinate Dichotomy: Interpersonal Grammar and the Analysis of Adverbial Clauses in English. Berlin: Mouton de Gruyter.

Wiwel, H. G. 1901. Synspunkter for dansk sproglaere. København: Det Nordiske Forlag. 